\title{
Multisubstituted phthalonitriles, naphthalenedicarbonitriles, and phenanthrenetetracarbonitriles as precursors for phthalocyanine syntheses
}

\author{
Clifford C. Leznoff, Dmitri S. Terekhov, Colin R. McArthur, \\ Steven Vigh, and Jing Li
}

\begin{abstract}
Electrophilic aromatic nitration under mild conditions of 4-hydroxyphthalonitrile gave 4-hydroxy-3nitrophthalonitrile and 4-hydroxy-5-nitrophthalonitrile, while bromination yielded 3-bromo-4-hydroxyphthalonitrile, 4-bromo-5-hydroxyphthalonitrile, and 3,5-dibromo-4-hydroxyphthalonitrile. Iodination gave 4hydroxy-5-iodophthalonitrile and 4-hydroxy-3,5-diidophthalonitrile. Coupling of 4-iodophthalonitrile, 3iodophthalonitrile, and 5-iodo-2,3-dicyanonaphthalene with trans-1,2-bis(tri- $n$-butylstannyl)ethene gave trans1,2-bis(3,4-dicyanophenyl)ethene, trans-1,2-bis(2,3-dicyanophenyl)ethene, and trans-1,2-bis(6,7-dicyanonaphthyl)ethene. Photocyclization of a dilute solution of cis- or trans-1,2-bis(3,4-dicyanophenyl)ethene in dioxane gave a 1:1 mixture of 2,3,6,7- and 2,3,5,6-tetracyanophenanthrenes separable by chromatography.
\end{abstract}

Key words: phthalonitriles, naphthalenedicarbonitriles, phenanthrenetetracarbonitriles, electrophilic substitution.

\begin{abstract}
Résumé : La nitration électrophile aromatique du 4-hydroxyphtalonitrile, dans des conditions douces, conduit au 4-hydroxy-3-nitrophtalonitrile et au 4-hydroxy-5-nitrophtalonitrile alors que sa bromation fournit du 3-bromo-4-hydroxyphtalonitrile, du 4-bromo-5-hydroxyphtalonitrile, et du 3,5-dibromo-4-hydroxyphtalonitrile. L'iodation fournit du 4-hydroxy-5-iodophtalonitrile et du 4-hydroxy-3,5-diiodophtalonitrile. Le couplage des 4-iodophtalonitrile, 3-iodophtalonitrile et 5-iodo-2,3-dicyanonaphtalène avec du trans-1,2-bis(tri-n-butylstannyl)éthène fournit du trans-1,2-bis(3,4-dicyanophényl)éthène, du trans-1,2-bis(2,3-dicyanophényl)éthène et du trans-1,2-bis(6,7-dicyanonaphtyl)éthène. La photocyclisation d'une solution diluée des isomères cis-et trans-1,2-bis(3,4-dicyanophényl)éthène dans le dioxane fournit un mélange $1: 1$ des 2,3,6,7-et 2,3,5,6-tétracyanophénanthrènes que l'on peut séparer par chromatographie.
\end{abstract}

Mots clés : phtalonitriles, naphtalènedicarbonitriles, phénanthrènetétracarbonitriles, substitution électrophile.

[Traduit par la rédaction]

Some substituted aromatic $o$-dinitriles are widely used in the synthesis of phthalocyanines (1), polymers, and intermediates in organic syntheses (2). Most common methods of their synthesis include cyanation of aromatic halides (2) or more recently triflates (3), nucleophilic substitution of nitrophthalonitriles (46), aromatic coupling using, for example, 4-iodophthalonitriles mediated by palladium catalysts $(7,8)$, Diels-Alder addition of fumaronitrile or dicyanoacetylene to substituted dienes and furans (9), and multistep synthesis involving the transformation of aromatic $o$-diacids via imides and diimides (10) to dinitriles (11-13). Direct electrophilic aromatic substitution of aromatic $o$-dinitriles is generally not used owing to the presence of the two deactivating electron-withdrawing nitrile groups and the fact that these groups are susceptible to hydrolysis during the stronglv acidic conditions of these reactions. Our interests in

C.C. Leznoff,' D.S. Terekhov, C.R. McArthur, S. Vigh, and J. Li. Department of Chemistry, York University, North York (Toronto), ON M3J 1P3, Canada.

1 Author to whom correspondence my be addressed. phthalocyanine synthesis led us to prepare a variety of multisubstituted phthalonitriles, bisaromatic-o-dinitriles, naphthalenedicarbonitriles (5-substituted-2,3-dicyanonaphthalenes), and phenanthrenetetracarbonitriles, using a wide variety of methods including rarely used electrophilic aromatic substitution reactions and photocyclization.

Iodination, nitration, and bromination of 4-hydroxyphthalonitrile (1)

A recent paper by Gaude et al. (14) described the direct iodination of phenols by iodine nitrate and we thought that this procedure could be successful in the direct iodination of 4 . hydroxyphthalonitrile $(\mathbf{1})(15)$ as the two nitrile groups may not sufficiently deactivate phenol $\mathbf{1}$ towards electrophilic aromatic substitution. Thus, treatment of 1 with iodine nitrate in acetonitrile for $2 \mathrm{~h}$ at room temperature gave a mixture, separable by flash chromatography, of 4-hydroxy-3,5-diiodophthalonitrile (2) and 4-hydroxy-5-iodophthalonitrile (3) in 5 and $2.5 \%$ yield, respectively (Scheme 1 ).

The poor yields of $\mathbf{2}$ and $\mathbf{3}$ (probably as a result of the electron-deactivating cyano groups of 1 ) and the possibility of converting nitro groups into diazonium salts and iodo groups 
Scheme 1

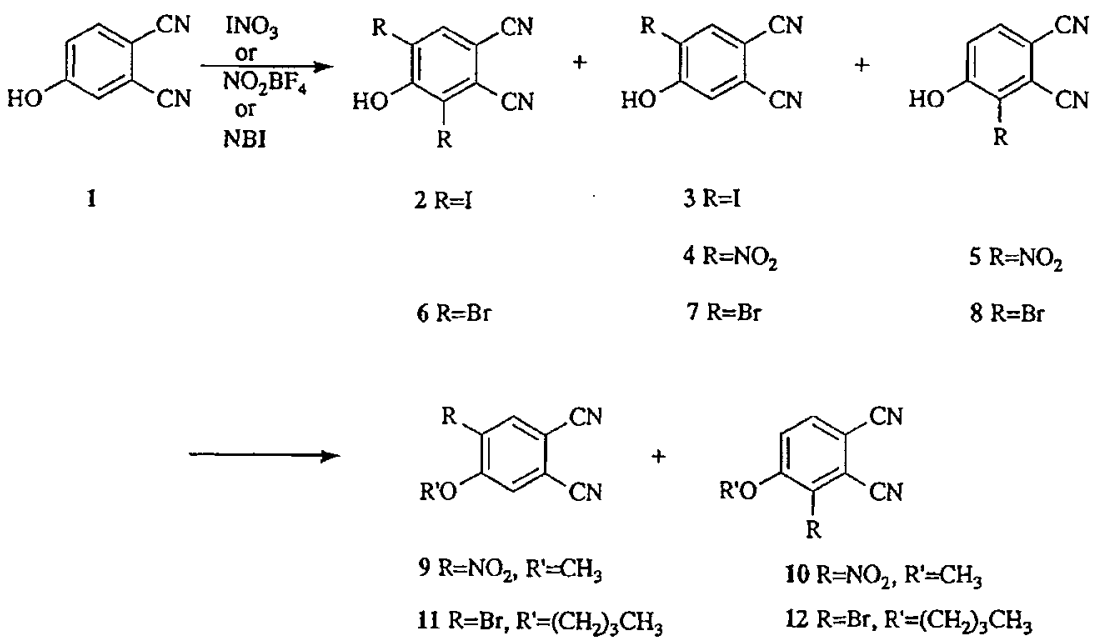

Scheme 2<smiles>CCCCCCc1c(C#N)cccc1[N+](=O)[O-]</smiles>

13<smiles>N#Cc1cccc(I)c1C#N</smiles><smiles>N#Cc1cccc(/C=C/c2cccc(C#N)c2C#N)c1C#N</smiles>

15

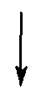<smiles>N#Cc1cccc(Cc2cccc(C#N)c2C#N)c1C#N</smiles>

18<smiles></smiles>

14

ed us to consider direct nitration of 1 , using the mild nitrating reagent nitronium tetrafluoroborate (16). Nitration of 1 with nitronium tetrafluoroborate in acetic acid at room temperature, followed by flash chromatography (17) and vacuum liquid chromatography (18) of the reaction mixture, gave 4-hydroxy-5-nitrophthalonitrile (4) and 4-hydroxy-3nitrophthalonitrile (5) in 15 and $13 \%$ yield, respectively (Scheme 1).

Since the yields of $\mathbf{4}$ and $\mathbf{5}$ were still unsatisfactory, we decided to try a rarely used brominating agent, $N, N$-dibromoisocyanuric (NBI) acid $(19,20)$ known to brominate aromatic compounds containing both activating and deactivating substituents. Although sulfuric acid is used in this procedure, the reaction time is short and the temperature low. Hence, 1 was reacted with NBI in concentrated sulfuric acid for $10 \mathrm{~min}$ at room temperature to give 3,5-dibromo-4-

hydroxyphthalonitrile (6) and a mixture of monobromo-4hydroxyphthalonitriles consisting of 4-bromo-5-hydroxyphthalonitrile (7) and 3-bromo-4-hydroxyphthalonitrile (8) in $72 \%$ yield that was inseparable by flash chromatography. Chromatography of the product mixtures of 4 and 5 and of 7 and 8 proved to be quite tedious. Hence the mixture of 4 and 5 was treated with diazomethane to give the less polar 4 methoxy-5-nitrophthalonitrile (9) and 4-methoxy-3-nitrophthalonitrile (10), while the mixture of 7 and 8 was alkylated using $\mathrm{K}_{2} \mathrm{CO}_{3}$ and 1-bromobutane to give 4-bromo-5butoxyphthalonitrile (11) and 3-bromo-4-butoxyphthalonitrile (12) in 30 and $34 \%$ overall yield from $\mathbf{1}$, respectively (Scheme 1).

\section{Bisdicyanoarylethenes from dicyanoiodoarenes}

Catalytic reduction of 3-nitrophthalonitrile (13) (21) with a poisoned palladium catalyst (22) gave 3-aminophthalonitrile (14) in $55-83 \%$ yields, which are considerably higher than previously reported (23). Diazotization of $\mathbf{1 4}$ and treatment of the diazonium salt with potassium iodide gave 3-iodophthalonitrile (15), only mentioned in an article but not characterized (24). Coupling of 15 with trans-1,2-bis(tri-nbutylstannyl)ethene (16) (25) gave trans-1,2-bis(2,3-dicyanophenyl)ethene (17) in $59 \%$ yield. In an attempt to prepare the cis isomer of 17 , iodo 15 was coupled with acetylene and a palladium catalyst $(7,8)$ to give 1,2 -bis $(2,3$ dicyanophenyl)ethyne (18). Catalytic hydrogenation of 18 over a Lindlar catalyst as previously described did not result in semi-hydrogenation and only starting material was recovered. Hydrogenation over palladium on charcoal afforded the fully saturated 1,2-bis(2,3-dicyanophenyl)ethane (19) (Scheme 2).

Bromination (9) of 2,3-dimethyl-1-nitrobenzene (20) gave 2-bromomethyl-3-dibromomethyl-1-nitrobenzene (21), which on treatment (9) with sodium iodide in N.N-dimethylformamide and fumaronitrile (22) yielded the known 5-iodo2,3-dicyanonaphthalene (23), prepared by a different route (26). Reduction of 23 (26), gave 5-amino-2,3-dicyanonaphthalene (24) (26), which upon diazotization and treatment with potassium iodide gave the unknown 5-iodonaphthalene-2,3dicarbonitrile (25). Coupling of 25 with 16 gave trans-1,2bis(6,7-dicyanonaphthyl)ethene (26) (Scheme 3). Both 
Scheme 3<smiles>Cc1cccc([N+](=O)[O-])c1C</smiles>

20<smiles>Cc1cccc([N+](=O)[O-])c1C</smiles>

21

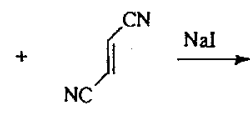

22<smiles>Cc1ccc2cc(C#N)c(C#N)cc2c1N</smiles>

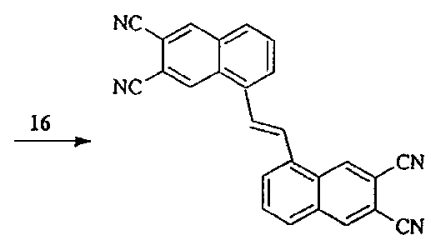

26<smiles>C#C[C@H](I)CCCN</smiles>

27 arylethenes 17 and 26 were extremely insoluble compounds, which likely caused attempts at subsequent reactions to fail. In an attempt to make a more soluble $c$ is isomer of $\mathbf{2 6}$, compound 25 was coupled with acetylene in the presence of copper iodide and bis(triphenylphosphine)palladium dichloride $(7,8)$ to give 1,2-bis(6,7-dicyanonaphthyl) ethyne (27) in $54 \%$ yield (Scheme 3). This highly insoluble compound also proved resistant to semi-hydrogenation.

\section{2,3,6,7-Tetracyanophenanthrene (31) and 2,3,5,6-tetra- cyanophenanthrene (32)}

Attempts to induce photocyclization (27-29) of 17 and 26 to give exclusively one isomer of tetracyanoarenes failed, probably because of their extreme insolubility. In a search for more soluble precursors, 4-iodophthalonitrile (28) (8) was coupled with 16 to give trans-1,2,bis (3,4-dicyanophenyl)ethene (29) in $94 \%$ yield. The cis isomer (30) has previously been made in our laboratory (26). Although 29 and $\mathbf{3 0}$ were both highly insoluble in most solvents, photocyclization of $\mathbf{2 9}$ and $\mathbf{3 0}$ was effected in a dilute solution of dioxane to afford a $1: 1$ mixture of 2,3,6,7-tetracyanophenanthrene (31) and 2,3,5,6-tetracyanophenanthrene (32) in 60-75\% yield (Scheme 4). Regioselectivity in stilbene-like photocyclization reactions can vary, depending on the substituent (30).

The separation of this mixture was finally achieved using flash chromatography and slow elution with ethyl acetate hexane (1:3) over 12 days to give pure $\mathbf{3 1}$ and $\mathbf{3 2}$. A third possible isomer, namely 3,4,5,6-tetracyanophenanthrene, was not detected in any of the photocyclization experiments.

\section{Spectroscopic analysis}

All nitriles exhibited typical nitrile absorption at 2220-2240 $\mathrm{cm}^{-1}$ in their infrared spectra. The NMR spectra of all compounds were consistent with their structures. The structure of the tribromo derivative 21 , however, was determined by the fact that long-range coupling occurred between the proton at $\mathrm{C}-4$ and the $\mathrm{CHBr}_{2}$ group to give a doublet of doublets (see

\section{Scheme 4}

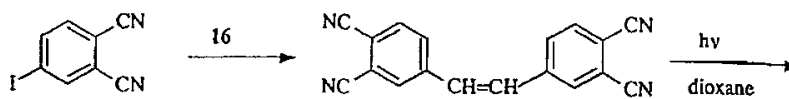

28

29 trans

$30 \mathrm{cis}$

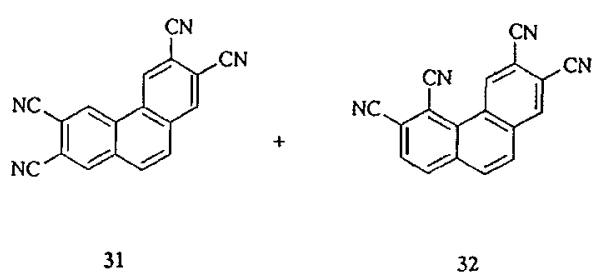

Experimental), and hence the $\mathrm{CHBr}_{2}$ group is at the 3 position.

A NOESY spectrum of compound 25 exhibited long-range coupling between the singlet at $8.88 \mathrm{ppm}(\mathrm{H}-\mathrm{Cl})$ and the doublet at $8.20 \mathrm{ppm}(\mathrm{H}-\mathrm{C} 8)$. Thus, the other singlet at $8.61 \mathrm{ppm}$ is $\mathrm{H}-\mathrm{C} 4$, the doublet at 8.49 is $\mathrm{H}-\mathrm{C} 6$, and the triplet at 7.62 is $\mathrm{H}-$ C7. The HH-COSY and NOESY spectra of 32 (Figs. 1 and 2) clearly exhibited a singlet at $9.03 \mathrm{ppm}(\mathrm{H}-\mathrm{Cl})$ coupled to a doublet at $8.31 \mathrm{ppm}(\mathrm{H}-\mathrm{ClO})$, while the singlet at $10.03 \mathrm{ppm}$ is uncoupled and is ascribed to $\mathrm{H}-\mathrm{C}$, which shows long-range coupling to $\mathrm{H}-\mathrm{C} 8$ at $8.65 \mathrm{ppm}$, leaving the remaining doublet at $8.47 \mathrm{ppm}$ for $\mathrm{H}-\mathrm{C} 7$. All new compounds exhibited parent ions in their mass spectra and satisfactory elementary analysis or high-resolution mass spectra (HRMS).

The ready availability of multisubstituted phthalonitriles, bisphthalonitriles, and tetracyanophenanthrenes will enable the preparation of unusual phthalocyanines.

\section{Experimental}

Matheson high-purity argon was used to maintain inert atmosphere conditions. Infrared (IR) spectra were recorded on a Pye Unicam SP1000 infrared spectrophotometer using $\mathrm{KBr}$ discs. Nuclear magnetic resonance (NMR) spectra for proton and carbon were recorded on a Bruker AM300 NMR spectrometer unless otherwise stated. TMS was used as the internal standard. The positions of the signals are reported in $\delta$ units. The splittings of the signal are described as singlets ( $s$, doublets (d), triplets (t), quartets $(q)$, pentets $(p)$, hextets $(h)$ doublets of doublets (dd), broad (br), or multiplets (m). The ultraviolet-visible spectra (UV-VIS) were recorded on a Varian CARY 2400 spectrophotometer UV-VIS-NIR. Mass spectra (MS) were recorded at $70 \mathrm{eV}$ using a VG Micromass $16 \mathrm{~F}$ mass spectrometer for molecules less than $900 \mathrm{amu}$ or a Kratos Profile in the EI mode. The number in parentheses after the indicated ion shows the percentage of the base peak represented by that ion. The high-resolution mass spectra (HRMS) were obtained at $70 \mathrm{eV}$ of a DEI model using a ZAB-E double focusing spectrometer of BE geometry. Melting points (mp) were determined using a Kofler hot stage melting point apparatus and are uncorrected. Flash chromatography was performed using silica gel of particle size $20-45 \mu \mathrm{m}$. All reactions were stirred with a magnetic stirrer. Ultrasound activation was carried out using a Branson 1200 sonicator. All 
Fig. 1. The ' $\mathrm{H}-{ }^{\prime} \mathrm{H}$ COSY NMR spectrum of 2,3,5,6-tetracyanophenanthrene (32) in DMSO-d .

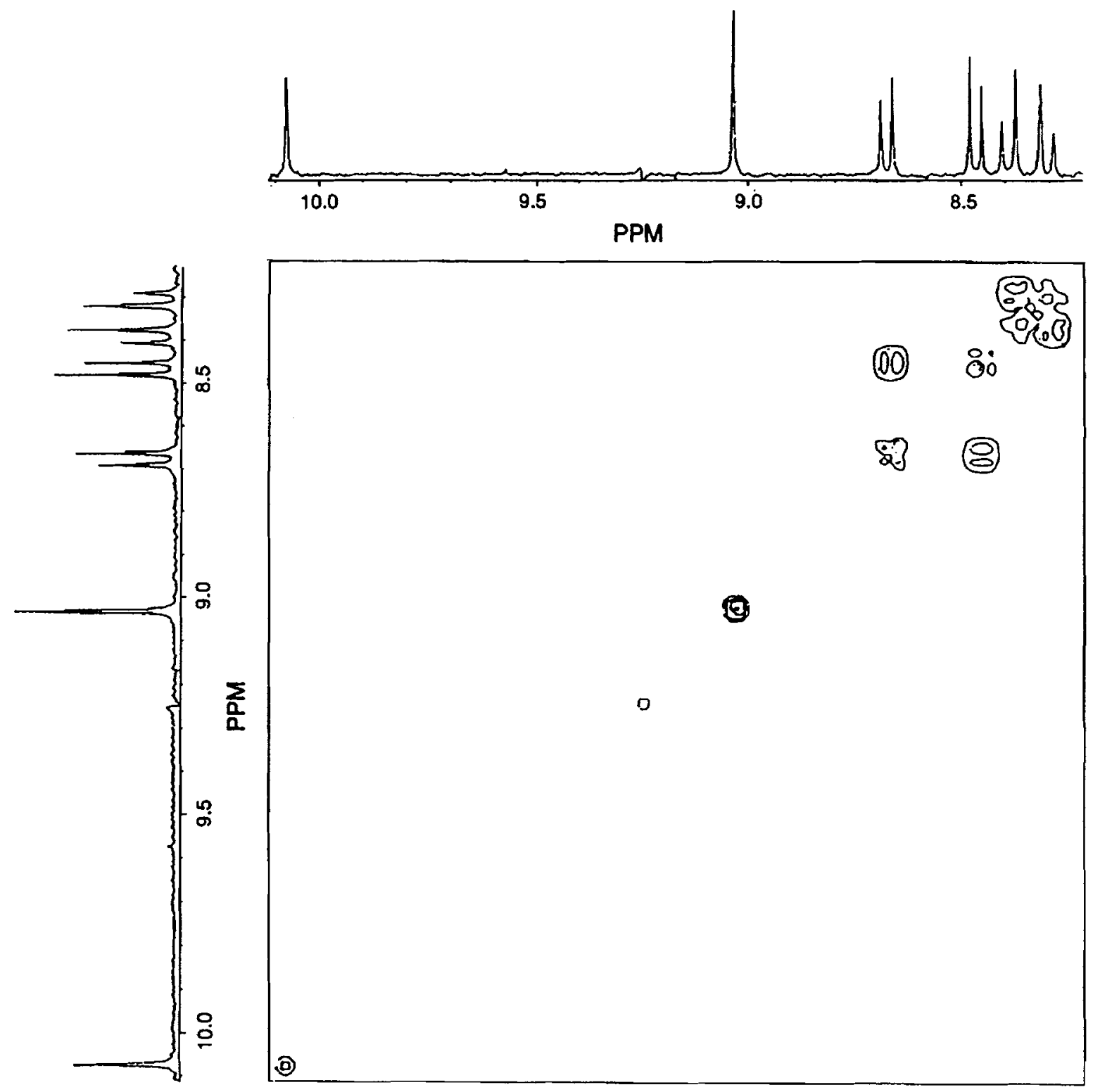

solvents were freshly distilled before use. Microanalysis were performed by Guelph Chemical Laboratory Ltd., Guelph, Ontario. Thin-layer chromatography (TLC) was performed using silica gel $\mathrm{G}$ as the absorbent.

\section{4-Hydroxy-3,5-diiodophthalonitrile (2) and 4-hydroxy-5- iodophthalonitrile (3)}

Silver nitrate $(0.85 \mathrm{~g}, 5 \mathrm{mmol})$ in $15 \mathrm{~mL}$ of acetonitrile was added dropwise to a solution containing $1.27 \mathrm{~g}$ of iodine (5 $\mathrm{mmol}$ ) in $30 \mathrm{~mL}$ of acetonitrile, while the solution was stirred at $0^{\circ} \mathrm{C}$. After $5 \mathrm{~min}$, the precipitate of silver iodide (about 2.5 $\mathrm{mmol})$ was filtered off and then compound $1(0.72 \mathrm{~g}, 5 \mathrm{mmol})$ in $10 \mathrm{~mL}$ of acetonitrile was added to the filtrate. The resulting solution was stirred at room temperature for $2 \mathrm{~h}$. An additional precipitate of silver iodide (about $2.5 \mathrm{mmol}$ ) was filtered off. The filtrate was washed with a solution of sodium bisulfite.
The organic layer was dried over anhydrous magnesium sulfate for $2 \mathrm{~h}$. The crude product was chromatographed on silica gel with petroleum ether and toluene (1:1). The first fraction gave a small amount of a yellow band. The second fraction was collected to give, in $5 \%$ yield, $70 \mathrm{mg}$ of compound $3 ; \mathrm{mp}$ $237-239^{\circ} \mathrm{C}$; IR $\left(\mathrm{KBr}, \mathrm{cm}^{-1}\right): 3320(\mathrm{OH}), 3070,2950,2900$, $2850,2230(\mathrm{CN}), 1570,1550,1480,1330,1280,1170,1120$, $900 ;{ }^{1} \mathrm{H}$ NMR (DMSO- $\left.d_{6}\right) \delta: 9.50(\mathrm{~s}, 1 \mathrm{H}, \mathrm{OH}), 8.52(\mathrm{~s}, 1 \mathrm{H}, \mathrm{H}-$ C6 or $H$-C3), $8.48\left(\mathrm{~s}, 1 \mathrm{H}, H\right.$-C 3 or $H$-C6); MS m/2: $270\left(\mathrm{M}^{+}\right.$, 100). Exact Mass calcd. for $\mathrm{C}_{8} \mathrm{H}_{3} \mathrm{~N}_{2} \mathrm{IO}: 269.9289$; found: 269.9289 . Further elution gave, in $2-3 \%$ yield, $52 \mathrm{mg}$ of compound $2 ; \mathrm{mp} 290^{\circ} \mathrm{C}$ (dec.); IR $\left(\mathrm{KBr}, \mathrm{cm}^{-1}\right)$ : $3360(\mathrm{O}-\mathrm{H})$, $2240(\mathrm{C} \equiv \mathrm{N}), 1550,1552,1440,1380,1302,1240,1130,920$; ${ }^{1} \mathrm{H}$ NMR (DMSO- $d_{6}$ ) $8: 8.43(\mathrm{~s}, 1 \mathrm{H}, H$-C6), 4.3 (br, s, $1 \mathrm{H}$, $\mathrm{OH}$ ). Exact Mass calcd. for $\mathrm{C}_{8} \mathrm{H}_{2} \mathrm{~N}_{2} \mathrm{I}_{2} \mathrm{O} ; 395.8255$; found: 395.8255 . 
Fig. 2. The 'H-'H NOESY NMR spectrum of 2,3,5,6-tetracyanophenanthrene (32) in DMSO- $d_{6}$.
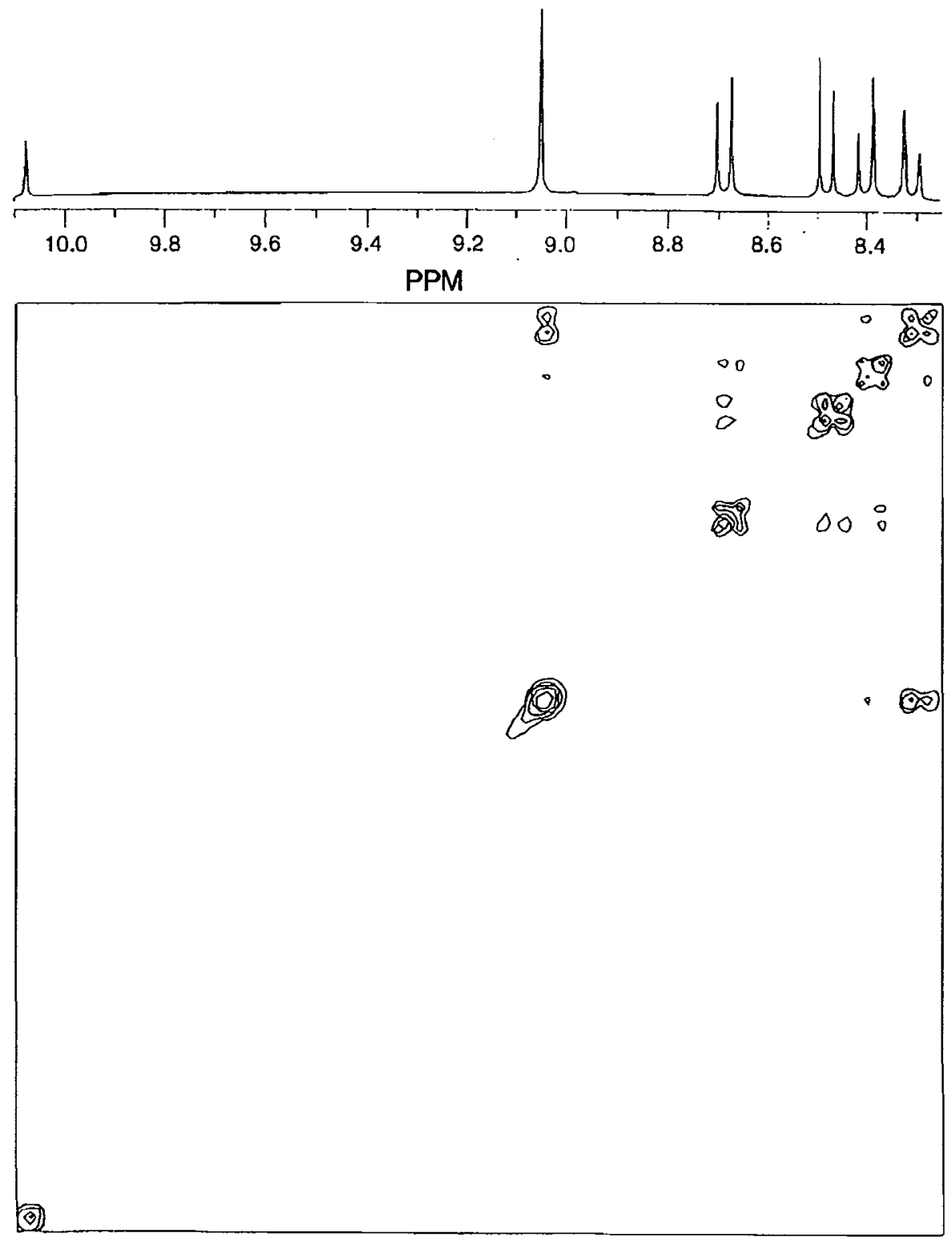

4-Hydroxy-5-nitrophthalonitrile (4) and 4-hydroxy-3-nitrophthalonitrile (5)

To a $50 \mathrm{~mL}$ round-bottomed flask, compound 1 ( $1 \mathrm{~g}, 6.9 \mathrm{mmol})$, nitronium tetrafluoroborate $(1.37 \mathrm{~g}, 10.35 \mathrm{mmol})$ (from Aldrich Chemical Company Ltd.), and $30 \mathrm{~mL}$ of acetic acid were added. The mixture was stirred at room temperature for $6 \mathrm{~h}$ and then poured into $100 \mathrm{~mL}$ of water. The resulting solution was extracted with ethyl acetate. The combined organic layer was washed with water and sodium bicarbonate solution and then dried over anhydrous magnesium sulfate. Magnesium sulfate was filtered off. The filtrate was chromatographed on a flash silica gel column by elution with ethyl acetate and hexane $(v / v=2: 1)$. The first fraction was collected to give, in $15-16 \%$ conversion, $200 \mathrm{mg}$ of compound 4 as a yellow solid; $\mathrm{mp} 182-$ $184^{\circ} \mathrm{C}$; IR $\left(\mathrm{KBr}, \mathrm{cm}^{-1}\right): 3280(\mathrm{OH}), 2250(\mathrm{C} \equiv \mathrm{N}), 1630,1565$ $\left(\mathrm{NO}_{2}\right), 1320\left(\mathrm{NO}_{2}\right), 1280,1120,740 ;{ }^{1} \mathrm{H}$ NMR $\left(\mathrm{DMSO}-d_{6}\right) \delta$ :
8.64 (s, $1 \mathrm{H}, H$-C6), 7.62 (s, $1 \mathrm{H}, H$-C 3 ), 4.3 (br, s $1 \mathrm{H}, \mathrm{OH}$; MS m/z: 189 (M+, 100). Anal. calcd. for $\mathrm{C}_{8} \mathrm{H}_{3} \mathrm{~N}_{3} \mathrm{O}_{3}: \mathrm{C} 50.81, \mathrm{H}$ 1.60, N 22.22; found: C 50.84, H 1.28, N 21.98. Continuous elution with the same eluant gave $500 \mathrm{mg}$ of the unreacted starting material 1. Further elution with ethyl acetate gave, in 13$14 \%$ conversion, $180 \mathrm{mg}$ of compound 5 , also as a yellow solid; $\mathrm{mp}>320^{\circ} \mathrm{C} ; \mathrm{IR}\left(\mathrm{KBr}, \mathrm{cm}^{-1}\right): 3400(\mathrm{OH}), 2230(\mathrm{C} \equiv \mathrm{N}), 1590$, $1530\left(\mathrm{NO}_{2}\right), 1475,1380,1340\left(\mathrm{NO}_{2}\right), 1270,840,690 ;{ }^{1} \mathrm{H} \mathrm{NMR}$ $\left(\right.$ DMSO- $\left.d_{6}\right) \delta: 7.75(\mathrm{~d}, J=9 \mathrm{~Hz}, 1 \mathrm{H}, H$-C6), $7.04(\mathrm{~d}, J=9 \mathrm{~Hz}$, $1 \mathrm{H}, \mathrm{H}$-C5); MS m/z: $189(\mathrm{M}+, 100)$. Exact Mass calcd. for $\mathrm{C}_{8} \mathrm{H}_{3} \mathrm{~N}_{3} \mathrm{O}_{3}$ : 189.0174 ; found: 189.0180 .

\section{3,5-Dibromo-4-hydroxyphthalonitrile (6), 4-bromo-5-hy-} droxyphthalonitrile (7), and 3-bromo-4-hydroxyphthalonitrile (8)

A solution of $10 \mathrm{~g}(35.2 \mathrm{mmol})$ of $N, N$-dibromoisocyanuric 
acid (NBI) (16) in $100 \mathrm{~mL}$ of concentrated $\mathrm{H}_{2} \mathrm{SO}_{4}$ was added in one portion to a solution of $7.8 \mathrm{~g}(54.2 \mathrm{mmol})$ of 4-hydroxyphthalonitrile (1) (12) in $100 \mathrm{~mL}$ of conc. $\mathrm{H}_{2} \mathrm{SO}_{4}$ at room temperature. The mixture was stirred for $10 \mathrm{~min}$ and then poured onto $800 \mathrm{~g}$ of ice. The resulting precipitate was filtered and the filtrate extracted three times with ethyl acetate. The extract was washed with water, a $2 \%$ solution of $\mathrm{NaHCO}_{3}$, water, and dried over anhydrous $\mathrm{MgSO}_{2}$. Evaporation of the solvent gave a mixture of products. Flash chromatography on silica gel and elution with ethyl acetate gave in the early fractions, in $12 \%$ yield, $2.0 \mathrm{~g}$ of 3,5-dibromo-4-hydroxyphthalonitrile (6) as a yellow-white solid, mp $269-271^{\circ} \mathrm{C}$, IR $\left(\mathrm{KBr}, \mathrm{cm}^{-1}\right)$ : 3280 $(\mathrm{OH}), 2214(\mathrm{CN}){ }^{1}{ }^{\mathrm{H}} \mathrm{NMR}\left(\mathrm{DMSO}-d_{6}\right) \delta: 11.16(\mathrm{~s}, 1 \mathrm{H}, \mathrm{O}-\mathrm{H})$, 8.38 (s, $1 \mathrm{H}, H$-C6); MS $m / z: 302(\mathrm{M}+, 100)$. Anal. calcd. for $\mathrm{C}_{8} \mathrm{H}_{2} \mathrm{Br}_{2} \mathrm{~N}_{2} \mathrm{O}: \mathrm{C} 31.83, \mathrm{H} 0.67, \mathrm{~N} 9.28$; found: $\mathrm{C} 31.82, \mathrm{H} 0.65$, $\mathrm{N} 9.00$.

Further elution with ethyl acetate and evaporation of the solvent gave $2.1 \mathrm{~g}$ of a mixture of monobromo compounds. The original precipitate was extracted four times with ethyl acetate (leaving a residue of isocyanuric acid) and the extract dried, filtered, and evaporated as above to give an additional $6.6 \mathrm{~g}$ for an overall yield of $72 \%$ of an inseparable mixture of 4-bromo5-hydroxyphthalonitrile (7) and 3-bromo-4-hydroxyphthalonitrile (8); $1 \mathrm{H}$ NMR (DMSO- $d_{6}$ ) $\delta: 11.16$ (s, O- $H$ ), 8.39 (s, $H$-C6 (7)), 8.08 (s, $H$-C3 (7), 7.81 (d, $H$-C6) (8)), $7.30(\mathrm{~d}, H$ C3 (8)).

\section{4-Methoxy-5-nitrophthalonitrile (9)}

To $30 \mathrm{mg}$ of compound $4(0.16 \mathrm{mmol})$ in $20 \mathrm{~mL}$ of anhydrous ether, diazomethane $(300 \mathrm{mg}$ ) in $30 \mathrm{~mL}$ of anhydrous ether was added dropwise at room temperature during a $30 \mathrm{~min}$ period. The evaporation of the ether gave, in $92 \%$ yield, $30 \mathrm{mg}$ of compound 9; mp 94-96 ${ }^{\circ} \mathrm{C}$; IR $\left(\mathrm{KBr}, \mathrm{cm}^{-1}\right)$ : 3060, 2940, $2220(\mathrm{C}=\mathrm{N}), 1900,1600,1550,1520\left(\mathrm{NO}_{2}\right), 1390,1350$, $1190,1100,980,750 ;{ }^{\prime} \mathrm{H}$ NMR $\left(\mathrm{CDCl}_{3}\right) \delta: 8.2(\mathrm{~s}, 1 \mathrm{H}, H$-C6), 7.5 (s, $1 \mathrm{H}, H$-C 3$), 4.1$ (s, $\left.3 \mathrm{H}, \mathrm{CH}_{3}\right)$; MS $m / z: 203\left(\mathrm{M}^{+}, 100\right)$. Anal. calcd. for $\mathrm{C}_{9} \mathrm{H}_{5} \mathrm{~N}_{3} \mathrm{O}_{3}: \mathrm{C} 53.2 \mathrm{1}, \mathrm{H} 2.48, \mathrm{~N} 20.68$; found: $\mathrm{C}$ $53.49, \mathrm{H} 2.29, \mathrm{~N} 20.53$.

\section{4-Methoxy-3-nitrophthalonitrile (10)}

To $30 \mathrm{mg}$ of compound $5(0.16 \mathrm{mmol})$ in $20 \mathrm{~mL}$ of anhydrous ether, diazomethane $(300 \mathrm{mg})$ in $30 \mathrm{~mL}$ of anhydrous ether was added dropwise at room temperature during a $30 \mathrm{~min}$ period. The solution was continuously stirred for $30 \mathrm{~min}$. The evaporation of the ether gave, in $89 \%$ yield, $29 \mathrm{mg}$ of compound 10; $\mathrm{mp} 110-112^{\circ} \mathrm{C}$; IR $\left(\mathrm{KBr}, \mathrm{cm}^{-1}\right): 3090,2980,2240$ $(\mathrm{C}=\mathrm{N}), 1920,1600,1540\left(\mathrm{NO}_{2}\right), 14801360,1280,1060$, 850,$780 ;{ }^{1} \mathrm{H} \mathrm{NMR}\left(\mathrm{CDCl}_{3}\right) \delta: 7.91$ (d, $J=8.9 \mathrm{~Hz}, 1 \mathrm{H}, H$-C6), $7.41\left(\mathrm{~d}, J=8.9 \mathrm{~Hz}, 1 \mathrm{H}, H\right.$-C5), $4.07\left(\mathrm{~s}, 3 \mathrm{H}, \mathrm{CH}_{3}\right) ; \mathrm{MS} m / z$ : $\left(\mathrm{M}^{+}, 100\right)$. Anal. calcd. for $\mathrm{C}_{9} \mathrm{H}_{5} \mathrm{~N}_{3} \mathrm{O}_{3}: \mathrm{C} 53.21, \mathrm{H} 2.48, \mathrm{~N}$ 20.68; found: C 53.30, H 2.30, N 20.73.

\section{4-Bromo-5-butoxyphthalonitrile (11) and 3-bromo-4-bu- toxyphthalonitrile (12)}

To $50 \mathrm{~mL}$ of $\mathrm{N}, \mathrm{N}$-dimethylformamide (DMF) were added 4.0 $\mathrm{g}(18 \mathrm{mmol})$ of the mixture of 7 and $8,4.7 \mathrm{~g}$ of $\mathrm{K}_{2} \mathrm{CO}_{3}$, and 4.5 $\mathrm{g}$ of 1-bromobutane. The mixture was stirred at $90^{\circ} \mathrm{C}$ for $2 \mathrm{~h}$ and then poured into $200 \mathrm{~mL}$ of water. The mixture was extracted twice with benzene and the extract washed twice with water and dried over anhydrous $\mathrm{MgSO}_{4}$. The solvent was evaporated to give $7.6 \mathrm{~g}$ of a solid mixture. The mixture was separated by flash chromatography on silica gel using benzene-hexane (1:1) as eluant to give, in the first fractions, in 34\% yield, 4-bromo-5-butoxyphthalonitrile (11); mp 117 $119^{\circ} \mathrm{C}$; IR $\left(\mathrm{KBr}, \mathrm{cm}^{-1}\right): 2230(\mathrm{CN})$; ${ }^{1} \mathrm{H}$ NMR $\left(\mathrm{CDCl}_{3}\right)$ 8: 7.93 (s, 1H, H-C6), $7.18(\mathrm{~s}, 1 \mathrm{H}, H$-C 3$), 4.13(\mathrm{t}, J=4.2 \mathrm{~Hz}, 2 \mathrm{H}$, $\mathrm{OCH} 2), 1.88\left(\mathrm{~m}, 2 \mathrm{H}, \mathrm{OCH}_{2} \mathrm{CH}_{2}\right), 1.56\left(\mathrm{~m}, 2 \mathrm{H}, \mathrm{CH}_{3} \mathrm{CH}_{2}\right)$, 1.01 (t, $\left.J=4.9 \mathrm{~Hz}, 3 \mathrm{H}, \mathrm{CH}_{3}\right) ; \mathrm{MS} n / z: 278\left(\mathrm{M}^{+}, 31\right)$. Anal. calcd. for $\mathrm{C}_{12} \mathrm{H}_{11} \mathrm{BrN2O}$ : C 51.64, H 3.97, N 10.04; found: C $52.04, \mathrm{H} 4.03, \mathrm{~N} 10.02$.

Further elution gave 3-bromo-4-butoxyphthalonitrile (12) in $30 \%$ yield; $\mathrm{mp} 116-117^{\circ} \mathrm{C}$; IR $\left(\mathrm{KBr}, \mathrm{cm}^{-1}\right): 2235(\mathrm{CN}) ;{ }^{1} \mathrm{H}$ $\operatorname{NMR}\left(\mathrm{CDCl}_{3}\right) \delta: 7.79(\mathrm{~d}, J=5.8 \mathrm{~Hz}, 1 \mathrm{H}, H$-C6), $7.11(\mathrm{~d}, J=$ $5.8 \mathrm{~Hz}, H-\mathrm{C} 3), 4.14\left(\mathrm{t}, J=4.2 \mathrm{~Hz}, 2 \mathrm{H}, \mathrm{CH}_{2}\right), 1.87(\mathrm{~m}, 2 \mathrm{H}$, $\left.\mathrm{OCH}_{2} \mathrm{CH}_{2}\right), 1.55\left(\mathrm{~m}, J=3.7 \mathrm{~Hz}, 2 \mathrm{H}, \mathrm{CH}_{3} \mathrm{CH}_{2}\right), 1.00(\mathrm{t}, J=4.9$ $\left.\mathrm{Hz}, 3 \mathrm{H}, \mathrm{CH}_{3}\right)$; MS $m / z: 278\left(\mathrm{M}^{+}, 76\right)$. Anal. calcd. for $\mathrm{C}_{12} \mathrm{H}_{11} \mathrm{BrN}_{2} \mathrm{O}$ : C 51.64, H 3.97, N 10.04; found: C 51.76, H $3.86, \mathrm{~N} 9.95$.

\section{3-Aminophthalonitrile (14)}

Nitrophthalonitrile (13) (21) was prepared using the procedure of Campagna et al. $(12,13)$ in $95 \%$ yield. The selective reduction of 13 was facilitated using a poisoned catalyst $(22,23)$. A mixture of $2.5 \mathrm{~g}$ of $5 \%$ palladium on barium sulfate and $5 \mathrm{mg}$ of thiourea in $2.5 \mathrm{~mL}$ of methanol was shaken for $1 \mathrm{~h}$. The solvent was evaporated and the brown residue homogenized.

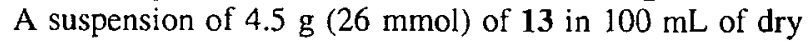
dioxane-ethanol (3:1) containing $750 \mathrm{mg}$ of the poisoned catalyst was hydrogenated at $30 \mathrm{psi}(1 \mathrm{psi}=6.9 \mathrm{kPa})$ in a Parr hydrogenation bottle for $1 \mathrm{~h}$ at room temperature. The yellow solution was concentrated and purified by flash chromatography using toluene-acetonitrile (5:1) as eluant to give $3.1 \mathrm{~g}$ (83\% yield) of 14 as a yellow powdery solid, $\mathrm{mp} 210-212^{\circ} \mathrm{C}$ (lit. (31) $\mathrm{mp} 195-198^{\circ} \mathrm{C}$ ).

\section{3-Iodophthalonitrile (15)}

Compound 14 (3.1 g, $21.7 \mathrm{mmol})$ was mixed with concentrated hydrochloric acid $(62 \mathrm{~mL})$ and ice $(155 \mathrm{~g})$, and sodium nitrite $(2.35 \mathrm{~g}, 34.1 \mathrm{mmol})$ in water $(20 \mathrm{~mL})$ was added in one portion. After $1.5 \mathrm{~h}$ at $5^{\circ} \mathrm{C}$, the solution was filtered. The diazonium salt solution was added dropwise to a stirred cool solution of potassium iodide in $30 \mathrm{~mL}$ of water. The resulting dark brown mixture was stirred for $0.5 \mathrm{~h}$. This mixture was added to benzene and the solution was washed with cold water, cold $5 \% \mathrm{NaHCO}_{3}$, cold water, cold saturated $\mathrm{Na}_{2} \mathrm{~S}_{2} \mathrm{O}_{3}$, and again with cold water. The benzene solution was dried over anhydrous magnesium sulfate, filtered, and concentrated to a small volume. Chromatography on $200 \mathrm{~g}$ of normal grade silica gel and elution with benzene gave, in $62 \%$ yield, $3.3 \mathrm{~g}$ of pure 15 as white crystals, mp $167-169^{\circ} \mathrm{C}$; $\mathrm{IR}\left(\mathrm{KBr}, \mathrm{cm}^{-1}\right): 3090,2240$ (CN), 1580, 1550, 1450, 1430, 1210, 1130, 810, 730; ${ }^{1} \mathrm{H}$ NMR $\left(\mathrm{CDCl}_{3}\right) 8: 8.16(\mathrm{~d}, J=8 \mathrm{~Hz}, 1 \mathrm{H}, \operatorname{Ar} H-6), 7.78(\mathrm{~d}, J=8 \mathrm{~Hz}$, $1 \mathrm{H}, \operatorname{Ar} H-4), 7.40(\mathrm{t}, J=8 \mathrm{~Hz}, 1 \mathrm{H}, \operatorname{Ar} H-5) ; \mathrm{MS} m / z: 254\left(\mathrm{M}^{+}\right)$, 202, 127, 100. Anal. calcd. for $\mathrm{C}_{8} \mathrm{H}_{3} \mathrm{~N}_{2} \mathrm{I}: \mathrm{C} 37.82, \mathrm{H} \mathrm{1.19}, \mathrm{N}$. 11.03, I 49.95; found: C-38.36, H I.10, N 11.20, I 49.81.

\section{trans-1,2-Bis(2,3-dicyanophenyl)ethene (17)}

To a $50 \mathrm{~mL}$ round-bottomed flask equipped with a magnetic stirrer were added 3 -iodophthalonitrile (15) $(132 \mathrm{mg}, 0.52$ $\mathrm{mmol}$ ), compound 16 (157.6 $\mathrm{mg}, 0.26 \mathrm{mmol})$, toluene $(25.0$ $\mathrm{mL}$ ), and tetrakis(triphenylphosphine) palladium $(0)(18.6 \mathrm{mg}$, $0.016 \mathrm{mmol}$ ). The resulting mixture was deoxygenated with a 
stream of argon for $5 \mathrm{~min}$. The reaction flask was placed in an oil bath at $100-120^{\circ} \mathrm{C}$ and stirred under argon at this temperature until TLC analysis indicated that 15 was consumed ( $10 \mathrm{~h})$. The reaction mixture was allowed to cool to room temperature and kept under argon overnight. The precipitate was filtered off and washed with toluene and diethyl ether to give, in $59 \%$ yield, $45 \mathrm{mg}$ of compound 17 as an off-white solid; $\mathrm{mp}$ $>330^{\circ} \mathrm{C}$; IR $\left(\mathrm{KBr}, \mathrm{cm}^{-1}\right): 3080,2230(\mathrm{C} \equiv \mathrm{N}), 1580,1470$, 1440, 1270, 1200, 1160, 801, 740. MS m/z: $280\left(\mathrm{M}^{+}, 100\right)$. Anal. calcd. for $\mathrm{C}_{18} \mathrm{H}_{8} \mathrm{~N}_{4}$ : C 77.14, H 2.86, N 20.00; found: C 77.24, H 2.39, N 20.27 .

\section{1,2-Bis-(2,3-dicyanophenyl)ethyne (18)}

By a procedure previously described $(7,8), 3.0 \mathrm{~g}(11.8 \mathrm{mmol})$ of $15,80 \mathrm{~mL}$ of dry, freshly distilled diethylamine, and $25 \mathrm{mg}$ ( $0.133 \mathrm{mmol}$ ) of bis(triphenylphosphine) palladium dichloride was placed into a $250 \mathrm{~mL}$ two-necked flask, equipped with a magnetic stirrer, a condenser, and a gas inlet tube. The flask was flushed with argon and a moderate stream of dry acetylene was passed through the solution for $9 \mathrm{~h}$ at room temperature. A pale pink precipitate was observed. This mixture was evaporated and the remaining residue was washed with water, methanol, and diethyl ether. The crude product was extracted with methanol in a Soxhlet extractor for $12 \mathrm{~h}$ until the extract was almost clear. This process removed brown impurities. The pale pink compound was dried to give, in $88 \%$ yield, $1.44 \mathrm{~g}$ of $18, \mathrm{mp}>300^{\circ} \mathrm{C}$. This product is sufficiently pure that it can be used directly without further purification. Two recrystallizations of a small sample of $\mathbf{1 8}$ from acetonitrile gave white crystals of pure $18, \mathrm{mp}>300^{\circ} \mathrm{C}$; IR $\left(\mathrm{KBr}, \mathrm{cm}^{-1}\right): 3090,2240(\mathrm{CN})$, $1590,1480,1450,1340,1290,1190,810,710 ;{ }^{1} \mathrm{H}$ NMR (DMSO- $d_{6}, 300 \mathrm{MHz}$ ) $\delta: 8.25$ (d, $J=8 \mathrm{~Hz}, 2 \mathrm{H}, \mathrm{Ar} H-6$ ), 8.16 (d, $J=8 \mathrm{~Hz}, 2 \mathrm{H}$, ArH -4$), 8.01(\mathrm{t}, J=8 \mathrm{~Hz}, 2 \mathrm{H}, \mathrm{Ar} H-50 ; \mathrm{MS}$ $\mathrm{m} / z: 278\left(\mathrm{M}^{+}\right), 251,224,200,176,139$. Anal. calcd. for $\mathrm{C}_{18} \mathrm{H}_{6} \mathrm{~N}_{4}: \mathrm{C} 77.69, \mathrm{H} 2.17, \mathrm{~N} 20.13$; found: C 77.42, H 2.08, N 20.78 .

\section{1,2-Bis-(2,3-dicyanophenyl)ethane (19)}

A suspension of $0.200 \mathrm{~g}(0.72 \mathrm{mmol})$ of 18 in $150 \mathrm{~mL}$ of acetonitrile containing $50 \mathrm{mg}$ of $10 \%$ palladium on charcoal was hydrogenated at $65 \mathrm{psi}$ in a Parr hydrogenation bottle for $4 \mathrm{~h}$ at room temperature. The clear solution was filtered from the catalyst and concentrated. The compound was purified by flash chromatography using acetonitrile as eluant to give $0.190 \mathrm{~g}$ (94\% yield) of 19 as yellow needles, mp $246-248^{\circ} \mathrm{C}$; IR (KBr, $\left.\mathrm{cm}^{-1}\right): 3090-2920,2230(\mathrm{CN}), 1590,1480,820,750 ;{ }^{\prime} \mathrm{H}$ NMR (DMSO- $\left.d_{6}, 300 \mathrm{MHz}\right) \delta: 8.01$ (d, $\left.J=8 \mathrm{~Hz}, 2 \mathrm{H}, \operatorname{Ar} H-6\right), 7.81$ $(\mathrm{t}, J=8 \mathrm{~Hz}, 2 \mathrm{H}, \operatorname{Ar} H-5), 7.72(\mathrm{~d}, J=8 \mathrm{~Hz}, 2 \mathrm{H}, \mathrm{Ar} H-4), 3.28$ (s, $4 \mathrm{H}, \mathrm{CH}_{2} \mathrm{CH}_{2} \mathrm{O}$; MS m/z: 282(M $\left.{ }^{+}\right), 255,226,201$, 141. Anal. calcd. for $\mathrm{C}_{18} \mathrm{H}_{10} \mathrm{~N}_{4}$ : C 76.58, H 3.57, N. 19.84; found: $\mathrm{C}$ 76.32, H 3.69, N 19.99 .

\section{2-Bromomethyl-3-dibromomethylnitrobenzene (21)}

To a $1000 \mathrm{~mL}$ one-necked round-bottomed flask, charged with $500 \mathrm{~mL}$ of carbon tetrachloride, 3-nitro-o-xylene (20) $(10 \mathrm{~g}$, $66 \mathrm{mmol}$ ) (from Aldrich Chemical Company Ltd), $N$-bromosuccinimide ( $70.88 \mathrm{~g}, 396 \mathrm{mmol}$ ), and $200 \mathrm{mg}$ of benzoyl peroxide were added. The mixture was irradiated using a $270 \mathrm{~W}$ sun lamp for $12 \mathrm{~h}$ or until TLC analysis indicated that the 3nitro-o-xylene (20) was consumed. A precipitate was formed and the hot solution was filtered. The filtrate was concentrated, preabsorbed on a small amount of flash silica gel, and then loaded on a $5 \mathrm{~cm}$ diameter column containing flash silica gel and eluted with cyclohexane. The second fraction was collected to give $17 \mathrm{~g}$ of compound 21 in $83 \%$ yield; $\mathrm{mp} 67-$ $68^{\circ} \mathrm{C}$ : IR ( $\left.\mathrm{KBr} \mathrm{cm}^{-1}\right): 3080,3020,1520$ (NO2), 1440, 1380 (NO2), 1255, 1230, 1140, 930, 850, 820, 780, 745, 680, 640; ${ }^{\prime} \mathrm{H} \mathrm{NMR}\left(\mathrm{CDCl}_{3}\right) \delta: 8.28\left(\mathrm{~d}, J=7.3 \mathrm{~Hz}, 1 \mathrm{H}, H-\mathrm{C}_{6}\right), 7.86(\mathrm{dd}$, $J=7.3,1.0 \mathrm{~Hz}, 1 \mathrm{H}, H-\mathrm{C} 4), 7.59(\mathrm{t}, J=8 \mathrm{~Hz}, 1 \mathrm{H}, H$-C5), 7.12 (brs, $\left.1 \mathrm{H}, \mathrm{CHBr})_{2}\right), 4.72\left(\mathrm{~s}, 2 \mathrm{H}, \mathrm{CH}_{2} \mathrm{Br}\right) ;{ }^{13} \mathrm{C} \mathrm{NMR}\left(\mathrm{CDCl}_{3}\right) \delta$ : 143.0, 135.0, 131.2, 130.2, 126.5, 125.9, 34.4, 21.4; MS m/z: $306\left(\mathrm{M}^{+}-79\right), 308,310,384\left(\mathrm{M}^{+}-1\right), 386,388,390$. Exact Mass calcd. for $\mathrm{C}_{8} \mathrm{H}_{6} \mathrm{Br}_{3} \mathrm{NO}_{2}: 383.7871\left(\mathrm{M}^{+}-\mathrm{H}\right)$; found 383.7873 .

\section{5-Aminonaphthalene-2,3-dicarbonitrile (24)}

Nitronaphthalene-2,3-dicarbonitrile (23), prepared from 19 and fumaronitrile (22) by the procedure of Kovshev et al. ( $9 a$ ), gave, upon hydrogenation as for the preparation of 13 above, the known $24, \mathrm{mp} 256-258^{\circ} \mathrm{C}$ (lit. (26) $\mathrm{mp} 257-258^{\circ} \mathrm{C}$ ).

\section{5-lodonaphthalene-2,3-dicarbonitrile (25)}

A solution of concentrated $\mathrm{H}_{2} \mathrm{SO}_{4}(12 \mathrm{~mL})$ and ice $(50 \mathrm{~g})$ was cooled to $0^{\circ} \mathrm{C}$ on a salt-ice bath. Compound $24(300 \mathrm{mg}, 1.6$ $\mathrm{mmol}$ ) was added to this solution followed by an aqueous solution of sodium nitrite $(176.5 \mathrm{mg}, 2.56 \mathrm{mmol}$ ). The resulting solution was stirred for $1 \mathrm{~h}$ at $0^{\circ} \mathrm{C}$ and then added dropwise to $20 \mathrm{~mL}$ of an aqueous solution of sodium iodide $(5 \mathrm{~g})$, which was vigorously stirred and kept below $3^{\circ} \mathrm{C}$. After $0.5 \mathrm{~h}$ at $3^{\circ} \mathrm{C}$, the dark brown solution was allowed to slowly warm to room temperature. Benzene ( $50 \mathrm{~mL}$ ) was added to the dark brown solution. After stirring for $10 \mathrm{~min}$, the resulting mixture was filtered. The organic layer was separated and washed with cold water, $10 \% \mathrm{NaHCO}_{3}$, cold water, a cold saturated solution of $\mathrm{Na}_{2} \mathrm{~S}_{2} \mathrm{O}_{3}$, again with cold water, and then dried over anhydrous magnesium sulfate for $2 \mathrm{~h}$. The magnesium sulfate was filtered off. The filtrate was concentrated to a small volume and chromatographed on a column containing regular grade silica gel using toluene as the eluant to give, in $46 \%$ yield, $270 \mathrm{mg}$ of compound 25 as a yellow solid; $\mathrm{mp} 243^{\circ} \mathrm{C}$; IR $\left(\mathrm{KBr}, \mathrm{cm}^{-1}\right): 3080,2240,(\mathrm{C} \equiv \mathrm{N}), 1540,1430,918,900$, $800 ;{ }^{1} \mathrm{H}$ NMR (DMSO- $\left.d_{6}\right) \delta: 8.88(\mathrm{~s}, 1 \mathrm{H}, H-\mathrm{Cl}), 8,61(\mathrm{~s}, 1 \mathrm{H}$, H-C 4$), 8.48$ (d, $J=8 \mathrm{~Hz}, 1 \mathrm{H}, H$-C6), 8.19 (d, $J=8 \mathrm{~Hz}, 1 \mathrm{H}, H_{-}$ C8), $7.62(\mathrm{t}, J=8 \mathrm{~Hz}, 1 \mathrm{H}, H-\mathrm{C} 7):{ }^{13} \mathrm{C}$ NMR (DMSO) $\left.-d_{6}\right) \delta$ : $142.3,139.4,137.5,134.0,133.0,132.0,129.8,116.0,115.9$, $110.8,109.9,100.3 ; \mathrm{MS} m / z: 304\left(\mathrm{M}^{+}, 100\right)$. Anal. calcd. for $\mathrm{C}_{12} \mathrm{H}_{8} \mathrm{~N}_{2}: \mathrm{C} 47.40, \mathrm{H} 1.66, \mathrm{~N} 9.21$; found: C 47.76, H 1.55, N 8.94 .

trans-1,2-Bis(6,7-dicyanonaphthyl)ethene (26)

To a $50 \mathrm{~mL}$ round-bottom flask equipped with a magnetic stirrer, 5-iodonaphthalene-2,3-dicarbonitrile (25) (300 mg, 0.96 $\mathrm{mmol}$ ), compound 16 (290 $\mathrm{mg}, 0.48 \mathrm{mmol})$, toluene $(25.0$ $\mathrm{mL}$ ), and tetrakis(triphenylphosphine)palladium(0) $(33.5 \mathrm{mg}$, $0.029 \mathrm{mmol}$ ) were added. The resulting mixture was deoxygenated with a stream of argon for $5 \mathrm{~min}$. The reaction flask was placed in an oil bath at $100-120^{\circ} \mathrm{C}$ and stirred under argon at this temperature until TLC analysis indicated that 25 was consumed (about $10 \mathrm{~h}$ ). The reaction mixture was allowed to cool to room temperature and remained under argon overnight. The precipitate was filtered and washed with toluene and diethyl ether to give, in $80 \%$ yield, $150 \mathrm{mg}$ of compound 
26 as a green-yellow solid; $\mathrm{mp}>330^{\circ} \mathrm{C}$; $\mathrm{IR}\left(\mathrm{KBr}, \mathrm{cm}^{-1}\right): 3050$, $2220(\mathrm{C} \equiv \mathrm{N}), 1450,1370,1360,1340,960,901,801,750$. Exact Mass calcd. for $\mathrm{C}_{26} \mathrm{H}_{12} \mathrm{~N}_{4}: 380.1061$; found: 380.1064 .

\section{1,2-Bis(6,7-dicyanonaphthyl)ethyne (27)}

Compound 25 ( $265 \mathrm{mg}, 0.87 \mathrm{mmol}$ ), $25 \mathrm{~mL}$ of dry, freshly distilled diethylamine, $25 \mathrm{mg}$ of copper(I) iodide (0.133 mmol), and $20 \mathrm{mg}$ of bis(triphenylphosphine)palladium dichloride $(0.028 \mathrm{mmol})$ were added to a $100 \mathrm{~mL}$ two-necked round-bottomed flask, which was equipped with a magnetic stirrer, a condensor, and a gas inlet tube. The flask was first flushed with argon and then a moderate stream of dry acetylene was bubbled though the solution for $6 \mathrm{~h}$ at room temperature. A brown precipitate was produced. The precipitate was filtered off and extracted continuously with methanol in a Soxhlet apparatus for about $12 \mathrm{~h}$, or until the extract was colourless. The precipitate in the thimble was dried in an oven at $100^{\circ} \mathrm{C}$ for $2 \mathrm{~h}$, to give, in $54 \%$ yield, $178 \mathrm{mg}$ of compound 27 as a brown solid; $\mathrm{mp}>330^{\circ} \mathrm{C}$; IR $\left(\mathrm{KBr}, \mathrm{cm}^{-1}\right): 3060,2230(\mathrm{C} \equiv \mathrm{N})$, 1580, 1260, 1180, 900, 800, 750; MS m/z: $378\left(\mathrm{M}^{+}, 100\right)$. Exact Mass calcd. for $\mathrm{C}_{26} \mathrm{H}_{10} \mathrm{~N}_{4}$ : 378.0905; found: 378.0917 .

trans-1,2-Bis(3,4-dicyanophenyl)ethene (29)

To a $50 \mathrm{~mL}$ round-bottomed flask equipped with a magnetic stirrer, 4-iodophthalonitrile (28) (517 mg, $1.96 \mathrm{mmol}$ ), compound 16 ( $594 \mathrm{mg}, 0.98 \mathrm{mmol}$ ), toluene $(5.0 \mathrm{~mL}$, freshly distilled over sodium), and tetrakis(triphenylphosphine)palla$\operatorname{dium}(0)(21.7 \mathrm{mg}, 0.018 \mathrm{mmol}$ ) (from Aldrich Chemical Company Ltd) were added. The resulting mixture was deoxygenated with a stream of argon for $5 \mathrm{~min}$. The reaction flask was placed in an oil bath at $100-120^{\circ} \mathrm{C}$ and stirred under argon at this temperature until TLC analysis indicated that 28 was consumed (about $10 \mathrm{~h}$ ). The reaction mixture was allowed to cool to room temperature and remained under argon overnight. The precipitate was filtered off and washed with toluene and diethyl ether to give, in $98 \%$ yield, $279 \mathrm{mg}$ of compound 29 ; $\mathrm{mp}>330^{\circ} \mathrm{C}$; IR $\left(\mathrm{KBr}, \mathrm{cm}^{-1}\right): 3050,2220(\mathrm{C} \equiv \mathrm{N}), 1590,1490$, $1415,1325,960,910,840,725 ;{ }^{1} \mathrm{H}$ NMR (DMSO- $d_{6}$ ) $8: 8: 41$ (s, $2 \mathrm{H}, H-\mathrm{C} 2), 8.17(\mathrm{~d}, J=8.2, H$-C5), $8.07(\mathrm{br}, \mathrm{d}, J=8.2,2 \mathrm{H}$, $H$-C6), 7.71 (s, 2H, $H \mathrm{C}=\mathrm{CH})$; $\mathrm{MS} \mathrm{m} / \mathrm{z}: 280\left(\mathrm{M}^{+}, 100\right)$. Anal. calcd. for $\mathrm{C}_{18} \mathrm{H}_{8} \mathrm{~N}_{4}$; C 77.13, H 2.88, N 19.95; found: C 76.96, H 2.57, N 19.64 .

\section{2,3,6,7-Tetracyanophenanthrene (31) and 2,3,5,6-tetra- cyanophenanthrene (32)}

To $90 \mathrm{~mL}$ of dioxane in a Pyrex tube $(40 \times 5 \mathrm{~cm})$, trans-29 $(40$ $\mathrm{mg}, 0.14 \mathrm{mmol}$ ) or cis-30 (26) (40 $\mathrm{mg}, 0.14 \mathrm{mmol})$ and iodine (25 $\mathrm{mg}, 0.19 \mathrm{mmol}$ ) were added. The suspension was sonicated until all particulates were dissolved. The tube was placed in a Rayonet photochemical reactor and irradiated for $9 \mathrm{~h}$ (the wavelength emitted by the lamps used was in the range of $257-350 \mathrm{~nm}$ ). In the irradiation of 29 a trace amount of precipitate was removed by filtration. The solution was washed with a saturated solution of sodium bisulfite and then with ethyl acetate. The organic layer was separated and dried over anhydrous $\mathrm{MgSO}_{4}$. After filtering the $\mathrm{MgSO}_{4}$, the solution was concentrated. The concentrated solution was preadsorbed on a small amount of flash silica gel, then loaded on a column containing TLC grade silica gel $\mathrm{G}$ and eluted slowly over a 12 day period with hexane - ethyl acetate (3:1). The first fraction gave, in 31 and $40 \%$ yield from 29 and 30 , respectively, 12.2 and $15.9 \mathrm{mg}$ of compound $31 ; \mathrm{mp}>330^{\circ} \mathrm{C}$; IR $\left(\mathrm{KBr}, \mathrm{cm}^{-1}\right)$ : 3065, 3040, $2240(\mathrm{C} \equiv \mathrm{N}), 1595,1245,920 ; 1 \mathrm{H}$ NMR $\left(\mathrm{DMSO}-d_{6}\right) \delta: 9.86(\mathrm{~s}, 2 \mathrm{H}, H$-Cl, $H$-C 8$), 8.99(\mathrm{~s}, 2 \mathrm{H}, H-\mathrm{C} 4$, $H$-C5), 8.33 (s, $2 \mathrm{H}, H$-C $9, H$-C 10 ); ${ }^{13} \mathrm{C}$ NMR (DMSO- $d_{6}$ ) $\delta$ : 136.1 134.2, 132.1, 130.6, 130.3, 116.1, 115.9, 112.6, 111.7; MS $m / z: 278\left(\mathrm{M}^{+}, 100\right)$. Anal. calcd. for $\mathrm{C}_{18} \mathrm{H}_{6} \mathrm{~N}_{4}: \mathrm{C} 77.69, \mathrm{H}$ 2.17, N 20.13; found: C 77.33, H 2.34, N 19.88.

Further elution with the same solvents gave, in 28 and $36 \%$ yields from 29 and 30 , respectively, 11.0 and $14.2 \mathrm{mg}$ of compound $32 ; \mathrm{mp}>330^{\circ} \mathrm{C}$; IR $\left(\mathrm{KBr}, \mathrm{cm}^{-1}\right): 3395,2220(\mathrm{C} \equiv \mathrm{N})$, $1585,925,870 ;{ }^{1} \mathrm{H}$ NMR (DMSO- $\left.d_{6}\right) \delta: 10.07$ (s, $1 \mathrm{H}, H$-C4), $9.03(\mathrm{~s}, 1 \mathrm{H}, H-\mathrm{Cl}), 8,67(\mathrm{~d}, J=8.4,1 \mathrm{H}, H-\mathrm{C} 8), 8.47$ (d, $J=$ $8.4,1 \mathrm{H}, H$-C7), 8.39 (d, $J=8.9,1 \mathrm{H}, H$-C 9 ), $8.3 \mathrm{l}$ (d, $J=8.9$, $1 \mathrm{H}, H$-C 10$) ;{ }^{13} \mathrm{C}$ NMR (DMSO- $d_{6}$ ) $\delta: 136.4,125.9,135.5$, $134.8,131.4,131.1,130.5,128.9,127.4,118.5,117.8,116.4$, $116.2,115.6,112.6,112.0,111.1 ; \mathrm{MS} m / 2: 278\left(\mathrm{M}^{+}, 100\right)$

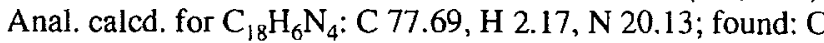
77.20, H 2.33, N 19.91 .

\section{Acknowledgement}

We are grateful to the Natural Sciences and Engineering Research Council of Canada for financial support of this research.

\section{References}

1. C.C. Leznoff. In Phthalocyanines; properties and applications. Vol. 1. Edited by C.C. Leznoff and A.B.P. Lever. VCH, New York. 1989. p.1.

2. G.P. Ellis and T.M. Romney-Alexander. Chem. Rev. 87, 779 (1987).

3. M.R.I. Chambers and D.A. Widdowson. J. Chem. Soc. Perkin Trans. I, 1365 (1989); K. Takagi and Y. Sakakibara. Chem. Lett. 1957 (1989).

4. T.M. Keller, T.R. Price, and J.R. Griffith. Synthesis, 613 (1980); N.P. Marullo and A.W. Snow. ACS Symp. Ser. 14, 325 (1982).

5. W.O. Siegl. J. Heterocycl. Chem. 18, 1613 (1981).

6. C.C. Leznoff, S.M. Marcuccio, S. Greenberg, A.B.P. Lever, and K.B. Tomer. Can. J. Chem. 63, 623 (1985).

7. S. Takahashi, Y. Kuroyama, K. Sonogashira, and N. Hagihara. Synthesis, 627 (1980); K. Sonogashira, Y. Tohoa, and H. Haginara. Tetrahedron Lett. 4467 (1975).

8. S.M. Marcuccio, P.I. Svirskaya, S. Greenberg, A.B.P. Lever, C.C. Leznoff, and K.B. Tomer. Can. J. Chem. 63, 3057 (1985).

9. (a) E.I. Kovshev, V.A. Puchnova, and E.A. Luk'yanets. Zh. Org. Khim. 7, 369 (1971), (b) M.J. Cook, M.F. Daniel, K.J. Harrison, N.B. McKeown, and A.J. Thomson. J. Chem. Soc. Chem. Commun. 1086 (1987).

10. R.A. McClelland, N.E. Seaman, J.M. Duff, and R.E. Branston. Can. J. Chem. 63, 121 (1985).

11. H.D.K. Drew and D.B. Kelly. J. Chem. Soc, 637 (1941); C.R. Rasmussen, J.F. Gardocki, J.N. Plampin, B.L. Twardzik, B.E. Reynolds, A.J. Molinari, N. Schwartz, W.W. Bennetts, B.E. Price, and J. Marakowski. J. Med. Chem. 21, 1044 (1978).

12. F. Campagna, A. Carotti, and G. Cassini. Tetrahedron Lett. 1813 (1977).

13. T.W. Hall, S. Greenberg, C.R. McArthur, B. Khouw and C.C. Leznoff. Nouv. J. Chim. 6, 653 (1982). 
14. D. Gaude, G. Gellon, R. le Goaller, and J. Pierre. Can. J. Chem. 67, 104 (1989).

15. V. A. Ustinov, V. V. Plakhtinskii, G. S. Mironov, and N. S. Ryabukhina. Zh. Org. Khim. 15, 1775 (1979).

16. S. J. Kuhn and G. A. Olan. J. Am. Chem. Soc. 83, 4564 (1961).

17. W. C. Still, M. Kahn, and A. Mitra. J. Org. Chem. 43, 2923 (1978).

18. N. M. Targett, J. P. Kilcoyne, and B. Green. J. Org. Chem. 44 4692, (1979).

19. W. Gottardi. Monatsh. Chem. 99, 815 (1968); 100, 42, (1969).

20. J. Rosevear and J. F. K. Wilshire. Aust. J. Chem. 33, 1561 (1977).

21. S. A. Mikhalenki, V. M. Derkacheva, and E. A. Luk'yanets. Zh. Obshch. Khim. 51, 1650 (1981).

22. H. Musso and H. Schroeder. Ber. Dtsch. Chem. Ges, 98, 1562 (1965).

23. J. Griffiths and B. Roozpeikar. J. Chem. Soc. Perkin Trans. 1, 42 (1976).
24. Yu. M. Osipov, G.P. Shaposhnikov, V.P. Kulinich, and R.P. Smirnov. Khim. Geterosikl. Soedin. 74 (1989).

25. J.C. Bottaro, R.N. Hanson, and D.E. Seitz. J. Org. Chem. 46, 5221 (1981); A. N. Nesmeyanov and A. E. Borisov. Dokl. Akad. Nauk SSSR, 174, 96 (1967).

26. E.I. Kovshev and E.A. Luk'yanets. Zh. Obshch. Khim. 42, 1593 (1972).

27. P. Hugelshofer, J. Kalvoda, and K. Schaffner. Helv. Chim Acta, 43, 1322 (1960).

28. F.B. Mallory, J.T. Gordon, and C.S. Wood. J. Am. Chem. Soc. 85, 829 (1963).

29. C.C. Leznoff and R.J. Hayward. Can. J. Chem. 48, 1842 (1970).

30. W.H. Laarhoven, Th. J.H.M. Cuppen, and R.J.F. Nivard. Tetrehedron, 26, 4865 (1970).

31. S. Vigh, H. Lam, P. Janda, A.B.P. Lever, C.C. Leznoff, and R.L. Cerny. Can. J. Chem. 69, 1457 (1991). 